\title{
Characterization of the Pyrolytic Products of Pine Nut Shells
}

\author{
S. Batbileg ${ }^{1}$, B. Purevsuren ${ }^{1}$, M. Battsetseg ${ }^{1}$, A. Ankhtuya ${ }^{1}$, D. Batkhishig ${ }^{1}$ \\ ${ }^{1}$ Institute of Chemistry and Chemical Technology, Mongolian Academy of Sciences, Ulaanbaatar-51, Mongolia
}

Correspondence: B. Purevsuren, Head of the laboratory of coal chemistry and technology, Institute of Chemistry and Chemical Technology, MAS, Ulaanbaatar-51, Mongolia. E-mail: bpurevsuren.icct@gmail.com

Received: April 22, 2019 Accepted: June 5, 2019 Online Published: June 20, 2019

doi:10.5539/ijc.v11n2p37 URL: https://doi.org/10.5539/ijc.v11n2p37

\begin{abstract}
Have been determined the technical characteristics and elemental composition of shells. The elemental composition of the shell was determined by a microanalytical method such as 5E C2000 model CNH-analyzer. The pyrolysis of shells investigated by using a standard quartz retort (tube) at different heating temperatures and determined the yields of pyrolysis products such as hard residue, tar, pyrolytic water, and gas. As a result of these experiments have been determined that $30 \%$ hard residue, higher yield $13 \%$ of tar, can be obtained at heating temperature $500^{\circ} \mathrm{C}$. Thermogravimetric analysis of shells carried out in TG/DTA7200, Hitachi, Japan model equipment. The shells' ash chemical composition was first time determined by the X-ray diffractions powder, that it consists of significantly higher $40 \%$ these chemical elements including manganese, nickel, little zinc, sulfur, aluminum, phosphorus, iron, magnesium, and calcium. The solubility of purified pyrolysis tar of shells in hexane, benzene and dichloromethane were investigated by using silicagel column and the chemical composition of each fraction determined by using of GC/MS chromatography system. The FTIR spectra of shell and pyrolysis tar determined by using of a Nicolet 20-PC spectrometer. The porosity structure of activated pyrolysis hard residue determined by the SEM analysis.
\end{abstract}

Keywords: quartz retort, column chromatography, tar, activated carbon

\section{Introduction}

Mongolia is a rich country with different kinds natural organic raw materials including oil, coals, oil shale, wood and bioorganic materials of animal origin such as casein, animal bone and huge amounts of wastes of wood and plants origin and also plastics and so on (Purevsuren et al., 2017). The pine nuts grow in the forest area of Khangai and Khentii high mountains in Mongolia, which is a very limited area of 683900 hectares. Pine nuts (cedar) are edible seeds of pines. The pine nuts shell usually calls only "shell". The shell must be removed before the processing pine nuts. Therefore the shell is a solid waste material. Usually, people throw away the shell and pollute the environment. In 2016 Mongolia had exported about $466 \mathrm{~kg}$ of unshelled pine nuts and it means that about $1000 \mathrm{~kg}$ of a shell thrown away as wastes.

On the other hand, pyrolysis is an efficient method of treatment of organic material at elevated temperatures in the absence of oxygen. It involves the simultaneous change of chemical composition and physical phase during thermochemical decomposition of organic material by heat and is irreversible (Davaajav \& Purevsuren, 2006). As a result of pyrolysis can be obtained solid (hard residue), condensed liquid (tar and pyrolysis water) and gas (uncondensed) products (gases). The solid product is porous material with a higher caloric value which can be used as coke, semicoke, smokeless fuel, adsorbent material and so on. Tar is a petroleum-like product and can be used as a complex raw material for the production of chemical substances, gasoline, diesel, oils and so on (Ariunaa et al., 2007). The gas product can be used as gas fuel after cleaning of nitrogen and sulfur-containing pollutants in it (Batbileg et al., 2015; Davaajav \& Purevsuren, 2006).

Before the pyrolysis experiments of organic raw materials have carried out a thermogravimetric analysis of these materials to determine the thermal stability characteristics such as thermostability indices $\left(\mathrm{T}_{5 \%}, \mathrm{~T}_{15 \%}\right.$ and $\left.\mathrm{T}_{25 \%}\right)$ and to evaluate how are easy for pyrolysis of them (Purevsuren, 1987). During the last decade, we are working on pyrolysis of some organic raw materials including different rank coals (Avid \& Purevsuren, 2002; Munkhjargal \& Purevsuren, 1998), oil shale (Avid, Purevsuren, \& Dugarjav, 2000; Purevsuren \& Ochirbat, 2016), wood waste (Otgonchuluun, Ariunaa, \& Purevsuren, 2015), animal bone (Davaajav \& Purevsuren, 2006; Purevsuren, Avid, Narangerel, Gerelmaa, \& Davaajav, 2004), shell (Purevsuren, 2012), polypropylene waste (Purevsuren, Davaajav, Karaca, et al., 2009), milk casein 
(Purevsuren \& Davaajav, 2001b, 2001a), and characterization of obtained hard residue, tar and gas product after pyrolysis.

\section{Experimental}

Shells (as waste material) are a powdered and dried solid product with yellow-brown color. The shell was crushed into pieces of 3-6 mm size and the analytical sample was prepared by powdering to a particle size $<0.2 \mathrm{~mm}$ in a steel mill.

Analytical sample preparation (MNS 2719: 2001), proximate and ultimate analysis of shell were performed according to Mongolian National Standards MNS 656-79 (moisture content), MNS 652-79 (ash yield), MNS 654-79 (volatile matter yield).

The elemental composition of the shell was determined by a microanalytical method such as 5E C2000 model $\mathrm{CNH}$-analyzer.

The FT-IR spectra of the shell were obtained on a Nicolet 20-PC FTIR spectrometer with CsI optics and DTGS detector. The $\mathrm{KBr}$ disc contained a $0.5 \%$ finely ground shell sample. All the spectra were measured in the frequency range of 4000 to $400 \mathrm{~cm}^{-1}$ and 32 scans were taken per sample.

Thermogravimetric analysis of shell carried out in TG/DTA 7200, Hitachi, Japan model equipment. Conditions of analysis were: Sample weight $5-10 \mathrm{mg}$. The heating temperature-range- $20-1150^{\circ} \mathrm{C}$, heating rate- $40^{\circ} \mathrm{C} / \mathrm{min}$, Carrier gasin nitrogen, Crucible- made by Pt-Rh.

The small-scale pyrolysis experiments of shell samples were performed in a laboratory quartz retort (tube) which could contain air-dried and powdered to a particle size $<0.2 \mathrm{~mm} 1 \mathrm{~g}$. of shell sample. The retort was placed in a horizontal electric tube furnace with a maximum heating temperature of $950{ }^{\circ} \mathrm{C}$. A chrome-alumni thermocouple was immersed in the tube furnace to measure the actual heating temperature. The pyrolysis experiments have been carried out at different heating temperatures $200-700{ }^{\circ} \mathrm{C}$ with a constant heating rate of $20{ }^{\circ} \mathrm{C} / \mathrm{min}$. First of all the quartz retort with the shell sample was heated for example to $600{ }^{\circ} \mathrm{C}$ with heating rate $20{ }^{\circ} \mathrm{C} / \mathrm{min}$. and kept at $700{ }^{\circ} \mathrm{C}$ for $80 \mathrm{~min}$. The retort was connected with a thermostable glass tube heated also in a tube furnace at $80^{\circ} \mathrm{C}$ for collecting of tars and this tube is also connected with an air-cooled glass vessel for collecting of pyrolysis water. The glass vessel for pyrolysis water is also connected with a thin glass tube for non-condensable gases. The yields of pyrolysis products including solid residue (biochar), tar (condensed liquid product) and pyrolysis water determined by weighing, and the yield of gases by differences.

The preparative scale pyrolysis experiments of shell samples were performed in a laboratory vertical cylindrical retort made by stainless steel which could contain 1000g. of a sample. The retort was placed in an electric furnace (model SNOL) with a maximum temperature of $950{ }^{\circ} \mathrm{C}$. A chrome-alumni thermocouple was immersed in the shell bed to measure the actual heating temperature and equipment for temperature control (potentiometer). The retort was connected with an air-cooled iron tube and water-cooled laboratory glass condenser and a collection vessel for the condensate of liquid product (tar and pyrolysis water). The non-condensable gases after water-cooled condenser were left the system through a thin glass tube. The experiments were carried out to $900^{\circ} \mathrm{C}$ temperature and the heating rate was $20{ }^{\circ} \mathrm{C} \mathrm{min}{ }^{-1}$. The yields of products including solid residue (biochar), tar and pyrolysis water determined by weighing, and the yield of gases by differences.

The liquid condensed by-product of shell pyrolysis consists from tar and pyrolysis water. They form an unmixed two layers and can be separated easily by separating the glass funnel. The upper layer is tar (viscous liquid) with a black-brown color and an unpleasant smell. The bottom layer is pyrolysis water (nonviscous liquid) with bad smell and yellow color. The final cleaning of tar from the pyrolysis water mixed with thermally treated $\mathrm{CaCl}_{2}$ and separating (filtering or centrifuging). The yellow-colored pyrolysis water has a specific gravity- $0.9227 \mathrm{~g} / \mathrm{cm}^{3}$ and solid residue-7.2\% after evaporation in room temperature.

The pyrolyzed shell samples (10-15g.) were placed in quarts tube and flowed with nitrogen to remove the oxygen and heated until $800^{\circ} \mathrm{C}$ and processed (activated) with heated water steam for $120 \mathrm{~min}$.

The column chromatography conditions of pyrolysis tar of shell as follows:

- Small glass column: $5.0 \mathrm{~mL}$

- Sample of tar $0.2 \mathrm{~g}$. for each solvent

- Used organic solvents (pure for chromatography): hexane, benzene and dichloromethane-20.0 $\mathrm{mL}$ from each solvent.

- Used sorbent: activated silica gel 4.0g.

The column chromatography carried out for obtaining the soluble in hexane $(\mathrm{H})$, benzene $(\mathrm{B})$ and dichloromethane $(\mathrm{M})$ fractions of the pyrolysis tar. These fractions were used as a mother solution for GC/MS analysis. The organic solvent 
was evaporated from the obtained fraction for the determination of the yield of each fraction.

The conditions of the GC/MS analysis of each fraction are:

-The analytical sample of each fraction: $1 \mu \mathrm{ml}$ of each fraction in $1 \mathrm{~mL}$ of each solvent.

-The sample of GC/MS analysis: $1 \mu \mathrm{ml}$ from each analytical sample

-Used apparatus: Agilent 7890A Agilent 5975C GC-MS system and capillary column J W DB-5.30mx, 0.25mm I.D. $0.25 \mu \mathrm{m}(122-5032)$.

-Carrier gas: $\mathrm{He}$

-Mass range: 50-550.

- Starting temperature of the furnace: $100^{\circ} \mathrm{C}$.

-Heating temperature and time: $2200 \mathrm{C}, 46 \mathrm{~min}$.

\section{Results and Discussion}

The proximate (basic technical characteristics) and ultimate (elemental composition) analysis of shells have been determined and the results are given in Table 1.

Table 1. Proximate and Ultimate analysis of shell

\begin{tabular}{lcccccccc}
\hline \multicolumn{2}{l}{ Proximate analysis, \% } & \multicolumn{6}{c}{ Ultimate analysis, \% } \\
\hline $\mathrm{W}^{\mathrm{a}}$ & $\mathrm{A}^{\mathrm{d}}$ & $\mathrm{V}^{\text {daf }}$ & $\begin{array}{l}\text { Q } \\
\mathrm{kcaf} / \mathrm{kg}\end{array}$ & $\mathrm{S}_{\text {total }}$ & $\mathrm{C}^{\text {daf }}$ & $\mathrm{H}^{\text {daf }}$ & $\mathrm{N}^{\text {daf }}$ & $\mathrm{O}^{\text {daf }}$ \\
\hline 9.97 & 0.69 & 75.90 & 4912.0 & 0.1 & 55.57 & 5.85 & 1.69 & 36.89 \\
\hline
\end{tabular}

Dates in Table 1 show, there is a very little amount of ash in the shell, because it is a pure organic raw material. When it is heating, the organic mass is easy to decompose then makes a lot of volatile substances. The organic substances have low resistance for heat. The hydrogen and nitrogen content are in the average like in coals. The photograph pictures of pine nut shells (A) and it's pyrolysis hard residue (B) are given in Figure 1.

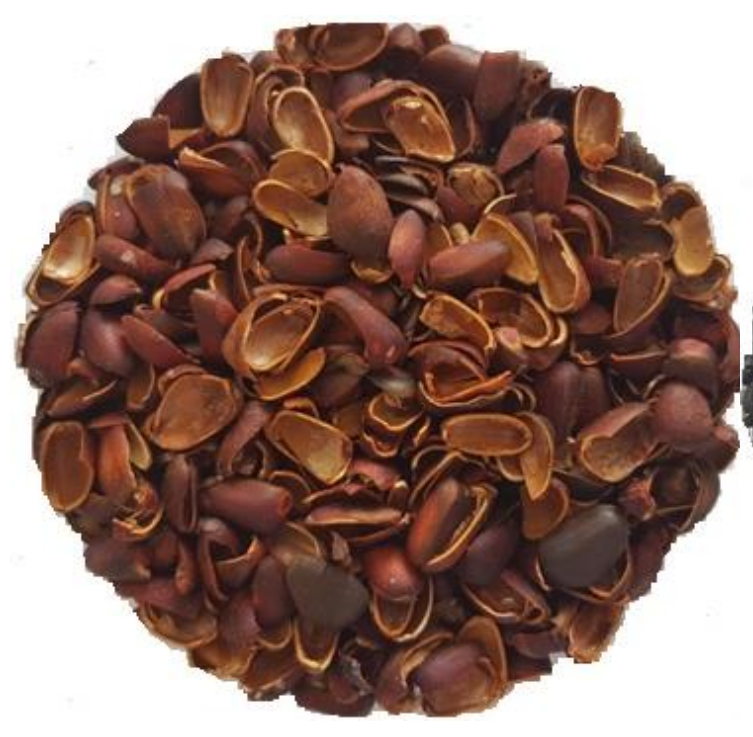

A

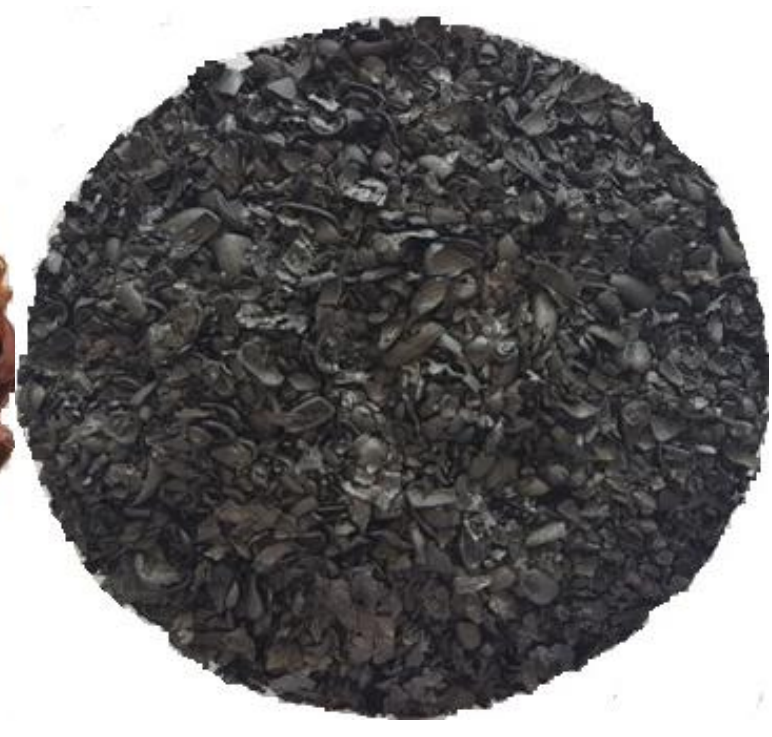

B

Figure 1. The photograph pictures of the shell (A) and it's pyrolysis hard residue (B)

As it is known the shell is a solid material thrown away after removing the Pine nuts ( are the edible seeds ) with brown color and therefore it is a waste material. To use this waste material we have used pyrolysis as a useful method for processing of the shell. After pyrolysis, the shell became a solid material (hard residue or biochar) with a black color.

The analytical sample of the shell was a subject for FTIR analysis and the results are shown in Figure 2. 


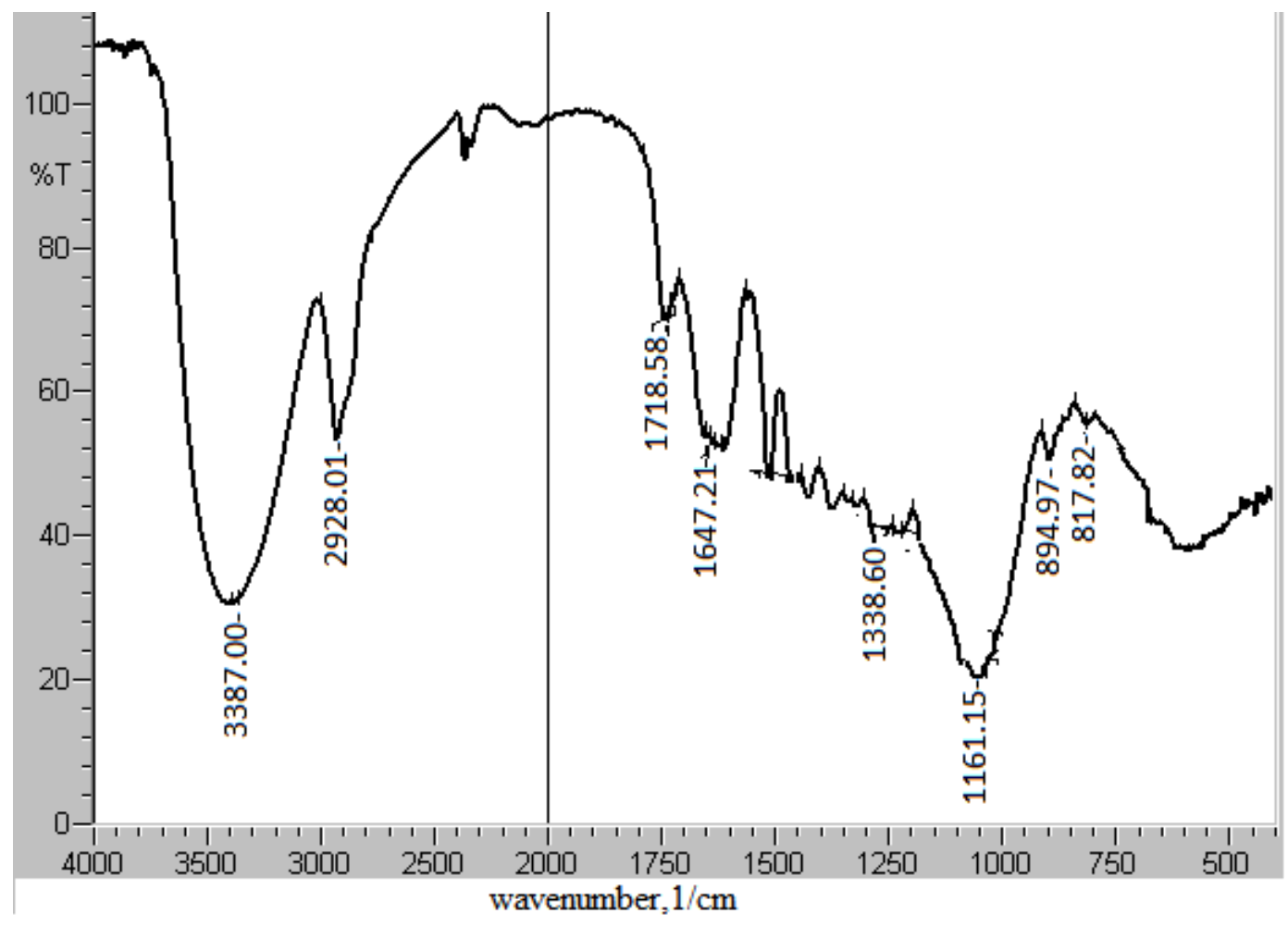

Figure 2. The FTIR spectra of shell

Figure 2 shows, in the FTIR spectra of shell has a very intensive unsharp pick at $3387 \mathrm{~cm}^{-1}$ for hydrogen from $\mathrm{OH},>\mathrm{NH}$, and $-\mathrm{NH}_{2}$ groups, a strong absorption band exists at $2926 \mathrm{~cm}^{-1}$ for aliphatic $>\mathrm{CH}_{2},-\mathrm{CH}_{3}$ and $>\mathrm{CH}$ - groups. A week band at $1718-1739 \mathrm{~cm}^{-1}$ for $-\mathrm{COOH}$ and a strong unsharp pick at $1652-1624 \mathrm{~cm}^{-1}$ for $>\mathrm{CO}$ groups. There are very little bands at $1608 \mathrm{~cm}^{-1}, 1338 \mathrm{~cm}^{-1}, 1319 \mathrm{~cm}^{-1}, 1271 \mathrm{~cm}^{-1}, 1228 \mathrm{~cm}^{-1}$ for $-\mathrm{C}-\mathrm{O}$ - groups, at $1161 \mathrm{~cm}^{-1}, 1109 \mathrm{~cm}^{-1}, 1055 \mathrm{~cm}^{-1}$, $1033 \mathrm{~cm}^{-1}$ for aromatic $-\mathrm{OH}$ groups and at $700-900 \mathrm{~cm}^{-1}$ for aromatic $-\mathrm{C}=\mathrm{C}$ - groups (Monkhoobor \& Batchimeg, 2009).

We have been collected the ash of shell during analysis and pyrolysis experiments and burned completely for analysis of the inorganic matters in a shell. The chemical composition of ash from the shell determined the first time by the X-ray diffractions powder and see from results, the content of $\mathrm{K}_{2} \mathrm{O}(48.3 \%)$ is highest and the content of $\mathrm{MgO}(15.3 \%), \mathrm{CaO}$ $(10.8 \%)$ is also higher. It was very interesting that the ash of shell has also some amounts of $\mathrm{Al}_{2} \mathrm{O}_{3}, \mathrm{SiO}_{2}, \mathrm{P}_{2} \mathrm{O}_{5}, \mathrm{SO}_{3}$, $\mathrm{Fe}_{2} \mathrm{O}_{3}, \mathrm{Mn}_{2} \mathrm{O}_{3}$ and $\mathrm{ZnO}(4.2 \%, 6.4 \%, 6.4 \%, 3.7 \%, 2.0 \%, 1.3 \%$, and $1.1 \%)$. The lowest content has only $\mathrm{CuO}$ and $\mathrm{NiO}$. Also, have been determined the value of the ratio between sum oxides $\left(\mathrm{Fe}_{2} \mathrm{O}_{3}+\mathrm{CaO}+\mathrm{MgO}+\mathrm{Na}_{2} \mathrm{O}+\mathrm{K}_{2} \mathrm{O}\right) /\left(\mathrm{SiO}_{2}\right.$ $\left.+\mathrm{Al}_{2} \mathrm{O}_{3}+\mathrm{TiO}_{2}\right)=7.19$ which is more than one $(>1.0)$ and this value is an indication that the ash of shell has a basic character. Also, the ash of shell was a subject for X-ray diffractions powder analysis and the results are given in Figure 3.

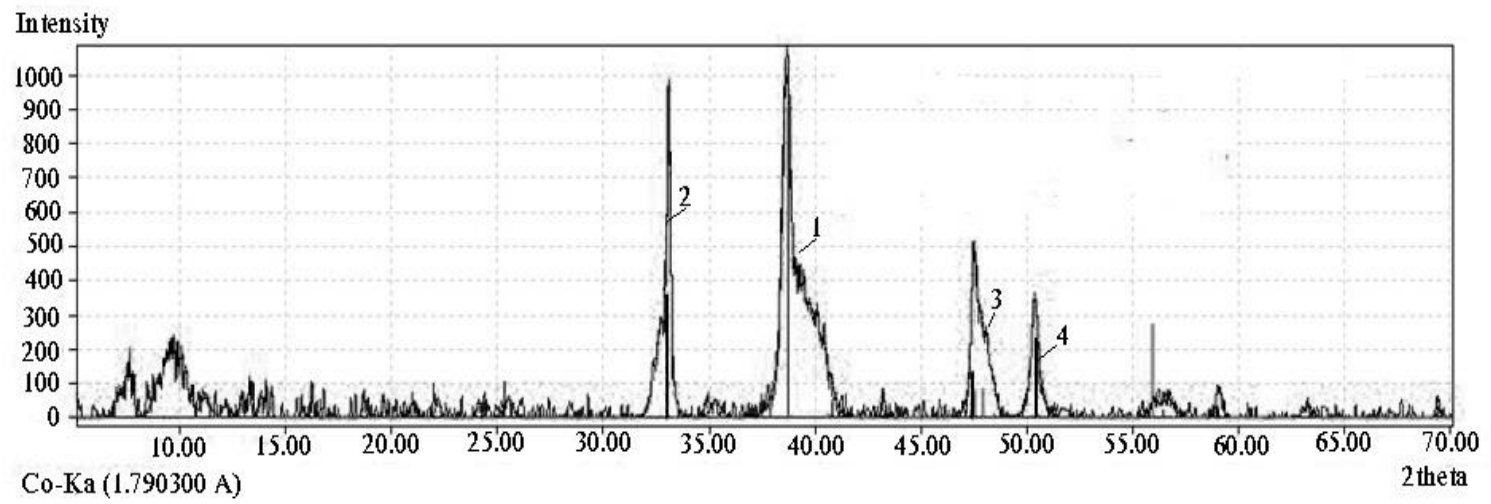

Figure 3. The X-ray diffractions powder of shell 
As a result of X-ray diffractions powder of shell ash have been determined that the shell ash consists mostly following minerals:

1-calcium aluminum oxide $\left(\mathrm{Ca}_{3} \mathrm{AI}_{2} \mathrm{O}_{6}\right) 66.61 \%$

2-Potassium Chloride (KCI) 26.49\%

3-Magnesium oxide (MgO) $5.70 \%$

4- Manganese oxide (MnO) $1.20 \%$

The analytical shell sample was investigated by thermogravimetric analysis and results are shown in Figure 4 .

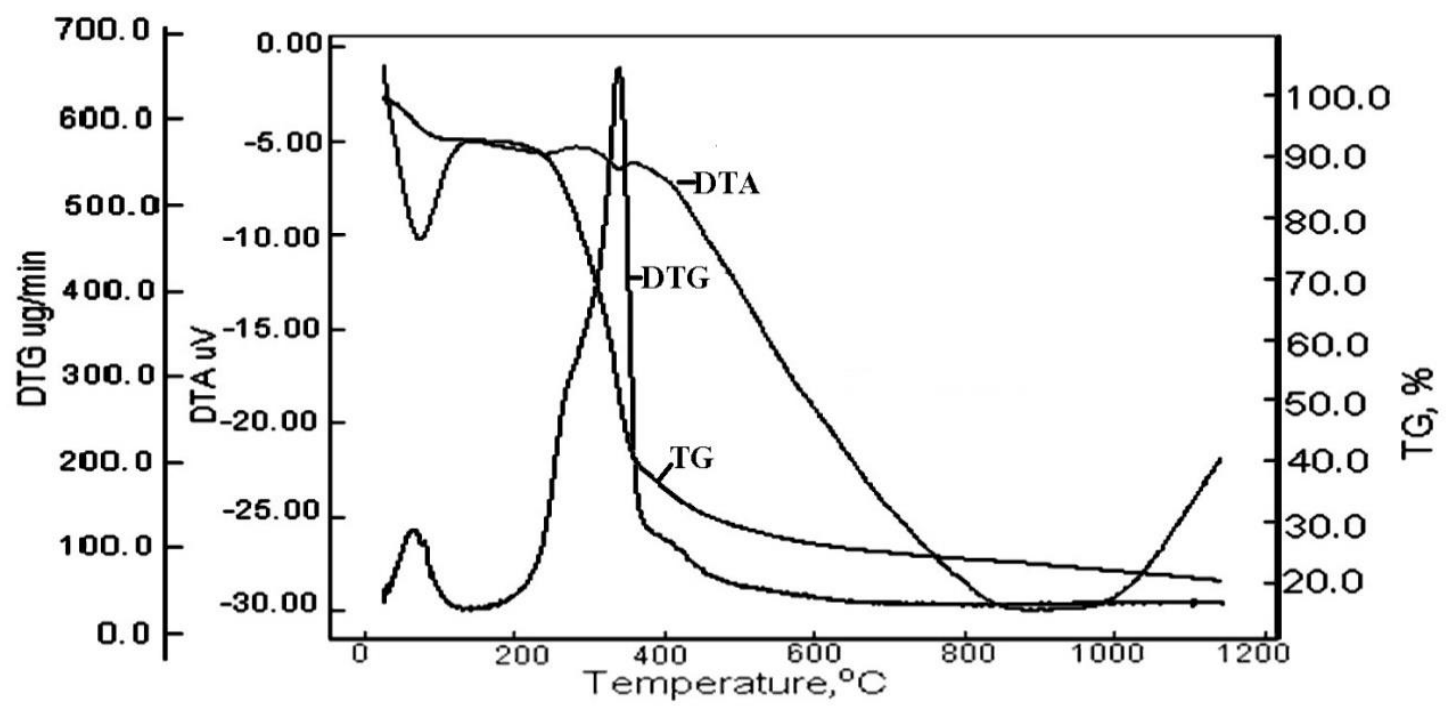

Figure 4. Thermogravimetric curves of shell

Heating of shell sample at $25-1100{ }^{\circ} \mathrm{C}$ temperatures in nitrogen atmosphere show that the thermal decomposition of shell ended with about $20 \%$ weight loss and $80 \%$ hard residue at $1100{ }^{\circ} \mathrm{C}$ (Figure 3). The TG curve in Figure 4 consists of different temperature intervals (steps) such as $30-170^{\circ} \mathrm{C} ; 170-395^{\circ} \mathrm{C} ; 395-700^{\circ} \mathrm{C} ; 700-1100^{\circ} \mathrm{C}$. In the first step $\left(30-170{ }^{\circ} \mathrm{C}\right)$ the weight loss belongs to releasing some absorbed gas and moisture from the shell sample. In the second step $\left(300-600^{\circ} \mathrm{C}\right)$ starts intensively thermal decomposition of the organic matter of shell sample and forming a liquid (tar and pyrolysis water) and gas products during the pyrolysis. In the third $\left(600-800^{\circ} \mathrm{C}\right)$ and fourth $\left(800-1100^{\circ} \mathrm{C}\right)$ steps the weight loss is decreasing intensively, which is an indication for finishing thermal decomposition and starting carbonization of shell sample. On the basis of TG curve (Weight loss, $\%$ vs Heating temperatures, ${ }^{\circ} \mathrm{C}$ in Figure 4 ) have been measured the thermal stability indices $\mathrm{T}_{5 \%}, \mathrm{~T}_{15 \%}, \mathrm{~T}_{25 \%}$ of the shell during it's thermal degradation in nitrogen atmosphere (Table 2). These indices are the temperatures in which the weight loss are 5\%, 15\% and 25\%.

Table 2. The thermal stability indices $\left(\mathrm{T}_{5 \%}, \mathrm{~T}_{15 \%}\right.$, and $\left.\mathrm{T}_{25 \%}\right)$ of shell

\begin{tabular}{llll}
\hline \multirow{2}{*}{ Sample } & \multicolumn{4}{l}{ Thermal stability indices, ${ }^{\circ} \mathrm{C}$} \\
\cline { 2 - 4 } & $\mathrm{T}_{5} \%$ & $\mathrm{~T}_{15} \%$ & $\mathrm{~T}_{25} \%$ \\
\hline Shell & 72.49 & 266.27 & 295.39
\end{tabular}

The values or these indices are comparatively lower and it means that the shell has lower thermal stability during its heating or pyrolysis.

Pyrolysis is one of an important process of utilization of organic raw materials including organic wastes for the production of solid, liquid and gas products. The pyrolysis experiments of shells carried out in a nitrogen atmosphere at different heating temperatures and determined the yields of obtained solid, condensed liquid and uncondensed gas products (Figure 5). 


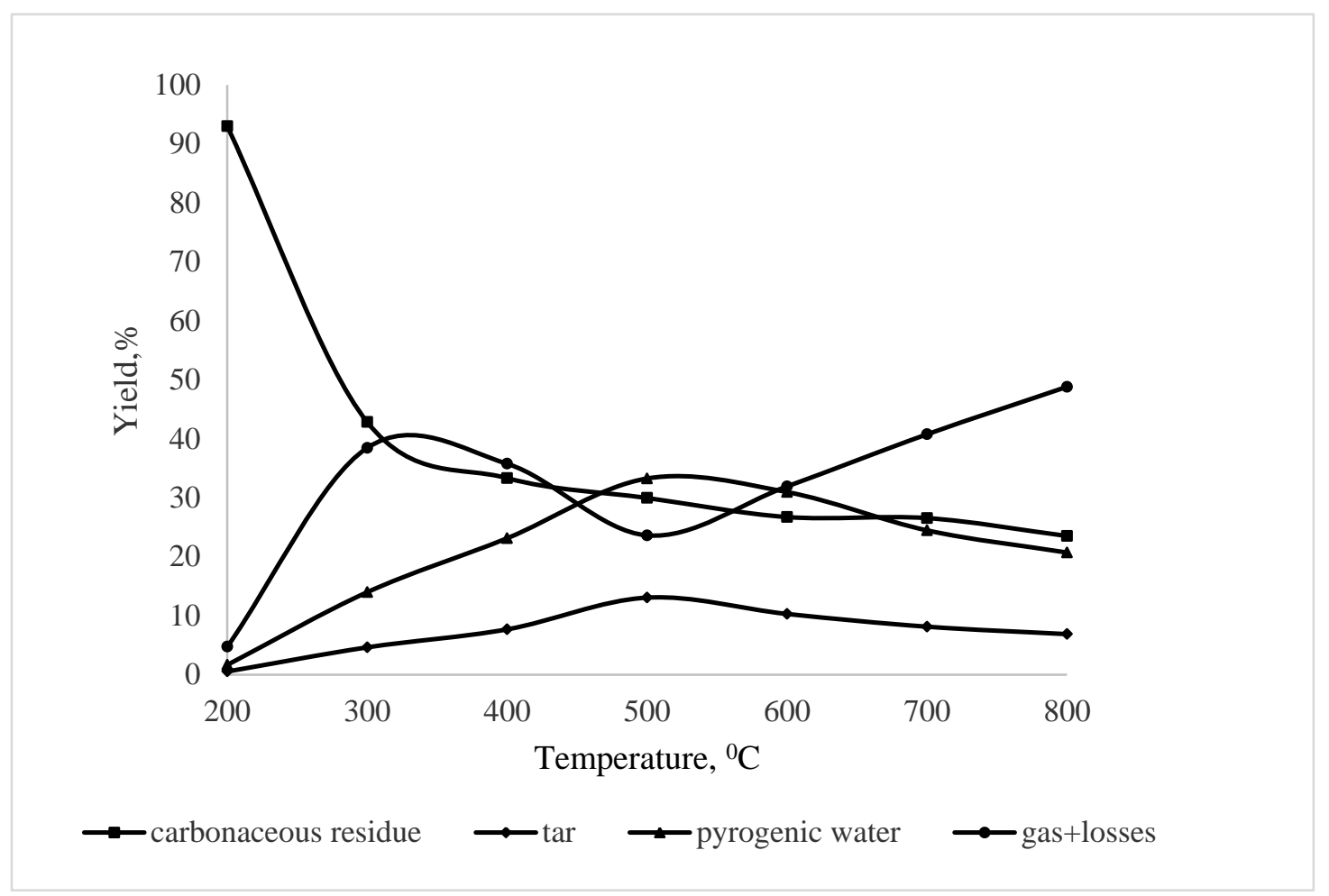

Figure 5. The yields of pyrolysis products of shell at different heating temperatures

Pyrolysis of the shell was performed in a standard laboratory quartz retort at different heating temperatures with constant heating rate $-20^{\circ} \mathrm{C} / \mathrm{min}$ and the yields of products include

ing biochar, tar, pyrolysis water determined by weighing and the yield of uncondensed gas by differences (Figure 5).

These results show that the yield of tar, pyrolysis water and gas increased with raising the temperature of pyrolysis. Only the yield of hard residue was decreased at the same time. The formed tar and hard residue were the most important products for us. Certainly, the yield of tar is lower at lower temperatures, because the thermal decomposition was not enough. The optimum temperature for pyrolysis of the shell was selected $500^{\circ} \mathrm{C}$, in which the yield of tar is higher-13.09\%.

The yields of pyrolysis products of shell obtained in this condition compared with the yields of other organic materials investigated by us are given in Table 3 .

Table 3. The yields of pyrolysis products of shell and other organic materials

\begin{tabular}{llllll}
\hline № & Name of materials & Hard residue, \% & Pyrolysis water, \% & Gas, \% & $\begin{array}{l}\text { Tar, } \\
\%\end{array}$ \\
\hline 1 & Shell & 29.98 & 33.29 & 23.64 & 13.09 \\
2 & Casein & 28.33 & 13.23 & 20.84 & 37.38 \\
3 & Animal bone & 70.00 & 7.60 & 17.47 & 4.92 \\
4 & Oil shale & 73.45 & 3.93 & 6.99 & 15.62 \\
5 & Brown coal & 68.31 & 7.14 & 15.54 & 8.71 \\
6 & Wood waste & 27.20 & 20.04 & 31.30 & 21.46 \\
\hline
\end{tabular}

Shell as a pure organic material like casein and wood has the lowest ash content and highest organic matter, therefore shell gives the lowest yield of hard residue and the higher yield of pyrolysis liquid (tar and pyrolysis water) and gas products (Table 3). In the case of animal bone, the yields of hard residue and pyrolysis liquid products are similar or same as for oil shale and brown coal (Table 3), because of its higher mineral matter and lower organic matter content (Purevsuren, Davaajav, F, et al., 2009).

Usually, the solid product can be used as a carbonaceous material, smokeless fuel, activated carbon and liquid product as a complex raw material for the production of chemical substances. Gas products can be used as gas fuel after 
cleaning of $\mathrm{N}$ and $\mathrm{S}$ containing gases. For this reason, we have been characterized by the solid and liquid products of the pyrolysis of the shell. First of all, have been determined the technical characteristics of the hard residue (solid product) after pyrolysis of the shell. The proximate analysis results, the volatile matter content decreased 10 times ( $\mathrm{V}$ daf $7.54 \%, \mathrm{~W}^{\mathrm{a}}-0.83 \%, \mathrm{~A}^{\mathrm{d}} 2.07$ and $\mathrm{Q}^{\mathrm{daf}}-7320.62 \mathrm{kcal} / \mathrm{kg}$ ) and much more increased caloric value in comparison with the initial shell characteristics in Table1, which are an indication for intensive thermal decomposition of the organic mass of the shell. Due to the carbonization process of its organic mass, there is slightly increasing the ash content.

To prepare an activated carbon-based on pyrolysis hard residue of the shell has been used an activation process at $800^{\circ} \mathrm{C}$ with preheated water steam for $80 \mathrm{~min}$. and obtained black colored carbonized solid material with high developed porosity structures visually. For evaluation, the adsorption capacity of the activated carbon and hard residue have been determined the adsorption value of methylene blue and iodine and the results are given in Table 4.

Table 4.The adsorption capacity of activated hard residue after pyrolysis

\begin{tabular}{llll}
\hline № & Sample & Adsorption of methylene blue, $\mathrm{mg} / \mathrm{g}$ & Iodine number, \% \\
\hline 1 & Hard residue after pyrolysis & 14.4 & 1.20 \\
2 & Activated hard residue & 358.0 & 54.3
\end{tabular}

The results in Table 4 show that the methylene blue adsorption valued strongly increased 25 times and iodine adsorption 45 times than that of pyrolysis hard residue, which are an indication for a good activated carbon with high developed porosity structures.

For the visual evaluation of the porosity structure of the activated carbon of shell have used SEM analysis and photographic pictures with different sizes are given in Figure 6.
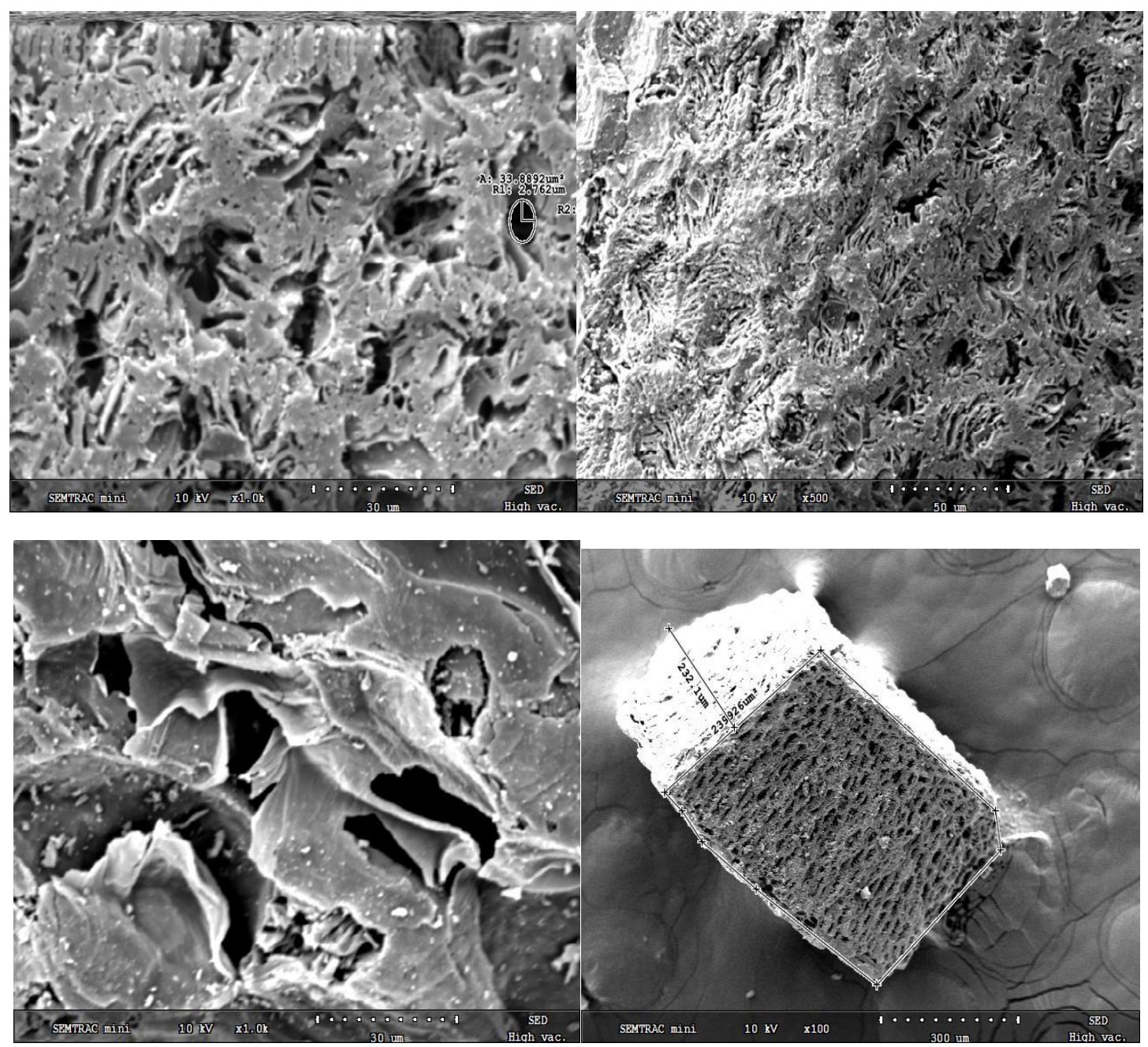

Figure 6. SEM photographs: of shell activated carbon of pyrolysis hard residue 
There are huge spread smoothly of waste shell pyrolysis solid residues. The SEM image different sizes activated carbon sample is high developed micro and mesoporous structure. The chemical analysis of methylene blue and iodine (Table 4) and SEM analysis results show that an activated carbon with good adsorption ability and high developed porosity structures can be prepared on the bases of pyrolysis hard residue of the shell.

As mentioned above the condensed liquid tar is one of the most important products of the pyrolysis. For this reason, we have been carried out more detailed investigations on characterization by spectrometric and chromatographic analysis. For example the FTIR spectra of pyrolysis tar of shell shown in Figure 7.

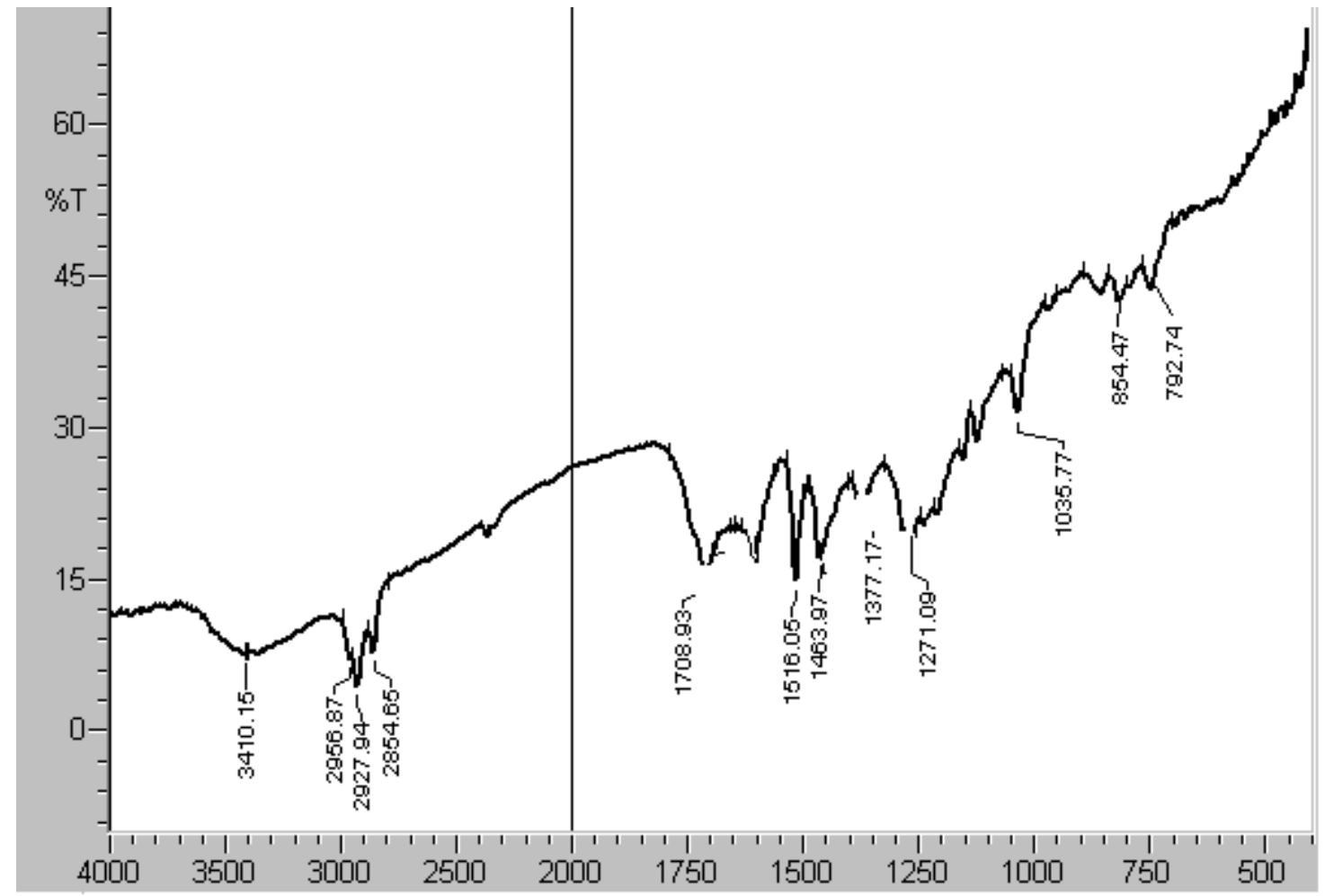

\section{wavenumber $1 / \mathrm{cm}$}

Figure 7. The FTIR spectra of pyrolysis tar of shell

There are in the FTIR spectra of pyrolysis tar of shell have poor picks of aromatic $-\mathrm{C}=\mathrm{C}$ - groups at 702-968 $\mathrm{cm}^{-1}$, picks with less intensity for aromatic -OH groups at $1035-1153 \mathrm{~cm}^{-1}$ and for $-\mathrm{C}-\mathrm{O}-$ groups at $1207-1377 \mathrm{~cm}^{-1}$, picks with more intensity for $>\mathrm{CO}$ groups at $1458-1516 \mathrm{~cm}^{-1}$ and for aliphatic $>\mathrm{CH}_{2},-\mathrm{CH}_{3}$ and $>\mathrm{CH}$ - groups at $2854-2958 \mathrm{~cm}^{-1}$, less intensive unsharp wide pick at 3410 and for $-\mathrm{COOH}$ groups at 1653-1708 and also for $>\mathrm{CO}$ groups at $1608 \mathrm{~cm}^{-1}$. The IR spectra of pyrolysis tar of shell show that the tar is multifunctional complex organic material with bad smelts and black-brown color (Monkhoobor \& Batchimeg, 2009).

As shown as, the chemical composition in group organic compounds of pyrolysis tar of shell that most part of the tar consists of neutral oils $89.5 \%$, the content of free carbons $5.4 \%$, phenols and asphaltenes are content $1.7 \%$ and $2.6 \%$, and less organic bases and acids than others $(0.1 \%$ and $0.7 \%)$.

Also, the pyrolysis tar of shell was distilled at room temperature and obtained 4 fractions with different boiling temperature range and the yields of fractions are given in Table 5. 
Table 5. The yield of distillation fractions of pyrolysis tar of shell with different boiling temperatures

\begin{tabular}{lllll}
\hline Boiling temperature range, ${ }^{\circ} \mathrm{C}$ & $\begin{array}{l}\text { Yield } \\
\text { fractions, } \%\end{array}$ & of & $\mathrm{n}$ & Appearance \\
\hline $\begin{array}{l}\text { From the beginning of boiling to } \\
180^{\circ} \mathrm{C} \text { хүртэл }\end{array}$ & 10.30 & 1.475 & Light fraction with white-yellow color \\
$180-250^{\circ} \mathrm{C}$ & 32.99 & 1.512 & Middle fraction with brown color \\
$250-280^{\circ} \mathrm{C}$ & 21.32 & 1.519 & Middle fraction with black-brown color \\
$280<$ & 35.39 & - & $\begin{array}{l}\text { Heavy fraction (distillation residue) with } \\
\text { black color }\end{array}$ \\
\hline
\end{tabular}

The data in Table 5 shows that two middle fractions have the highest content and a heavy fraction has higher content, only the light fraction has the lowest content.

The pyrolysis tar of shell was a subject of silica gel chromatography separation and hexane, benzene and dichloromethane are used as eluents. The yields of obtained fractions of soluble in hexane, benzene, and dichloromethane are given in Table 6 and determined the chemical compositions of each fraction by GC/MS chromatography are shown in Figure 8,9 and 10.

Table 6 . The yields of fractions of tar by silicagel chromatography, $\%$

\begin{tabular}{lllll}
\hline $\begin{array}{l}\text { Hexan soluble fraction } \\
(\mathrm{H})\end{array}$ & $\begin{array}{l}\text { Benzene soluble fraction } \\
\text { (B) }\end{array}$ & $\begin{array}{l}\text { Dichloromethane soluble fraction } \\
(\mathrm{M})\end{array}$ & $\begin{array}{l}\text { All } \\
\text { fractions }\end{array}$ & separated \\
\hline 1.58 & 18.91 & 14.59 & 35.08
\end{tabular}

The results of silica gel chromatography of shell tar show that most part of tar is soluble in benzene and less part of tar is soluble in hexane, which means that most parts of tar consist aromatic hydrocarbons.

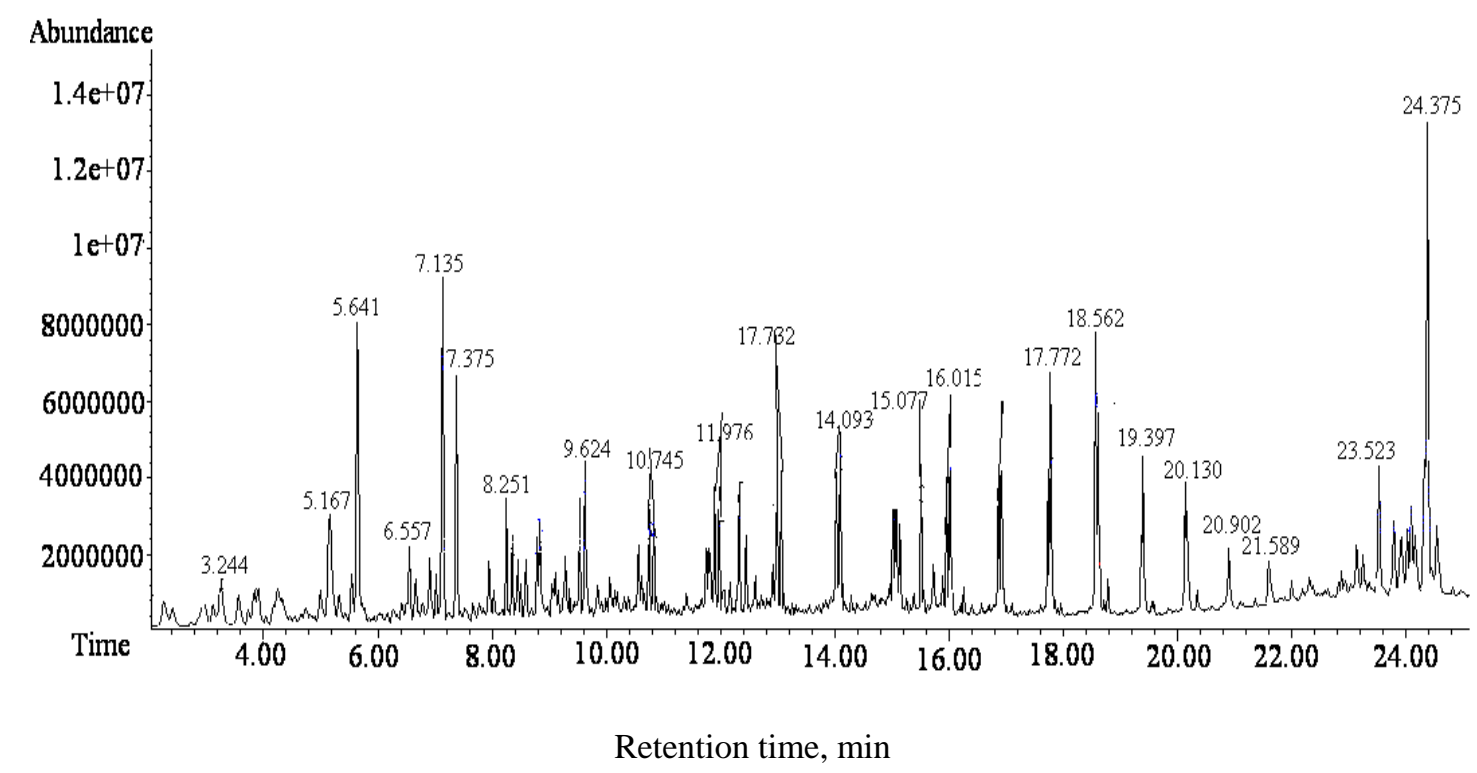

Figure 8. GC/MS chromatogram of hexane soluble fraction 


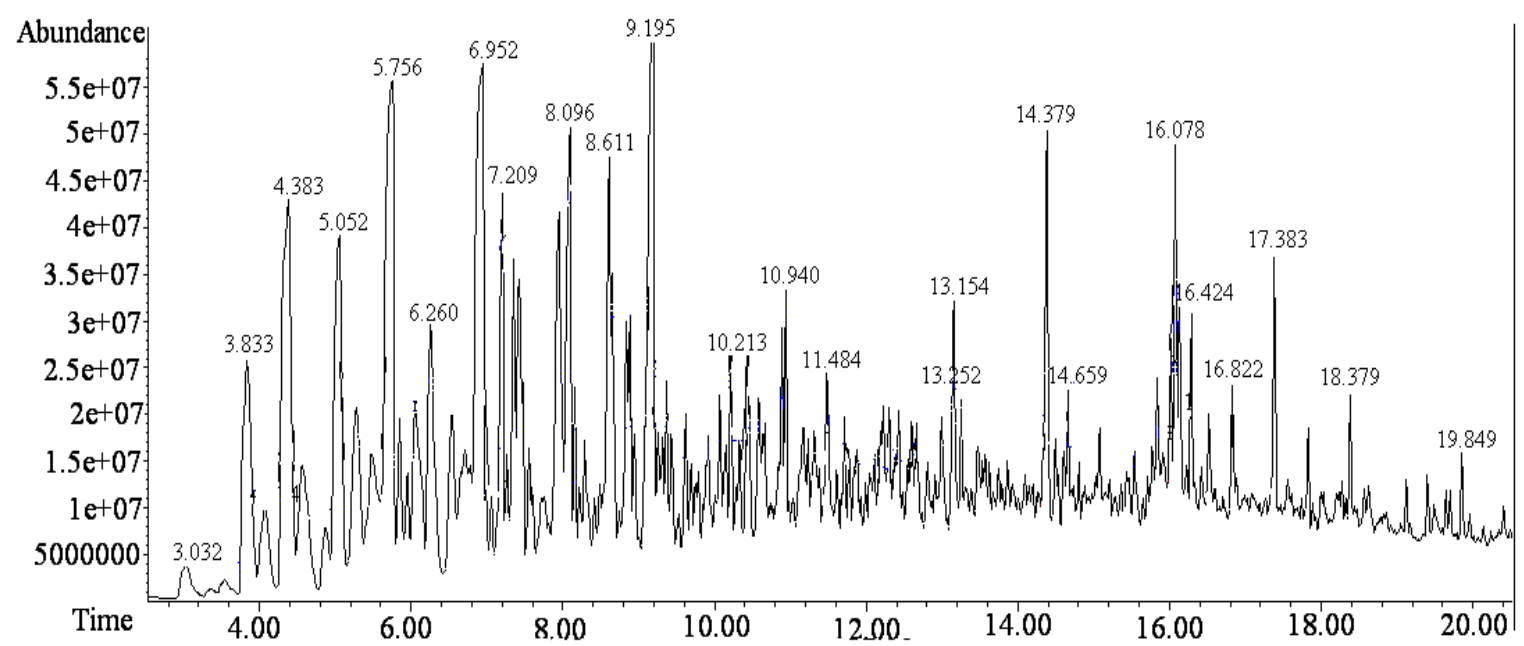

Retention time, min

Figure 9. GC/MS chromatogram of benzene soluble fraction

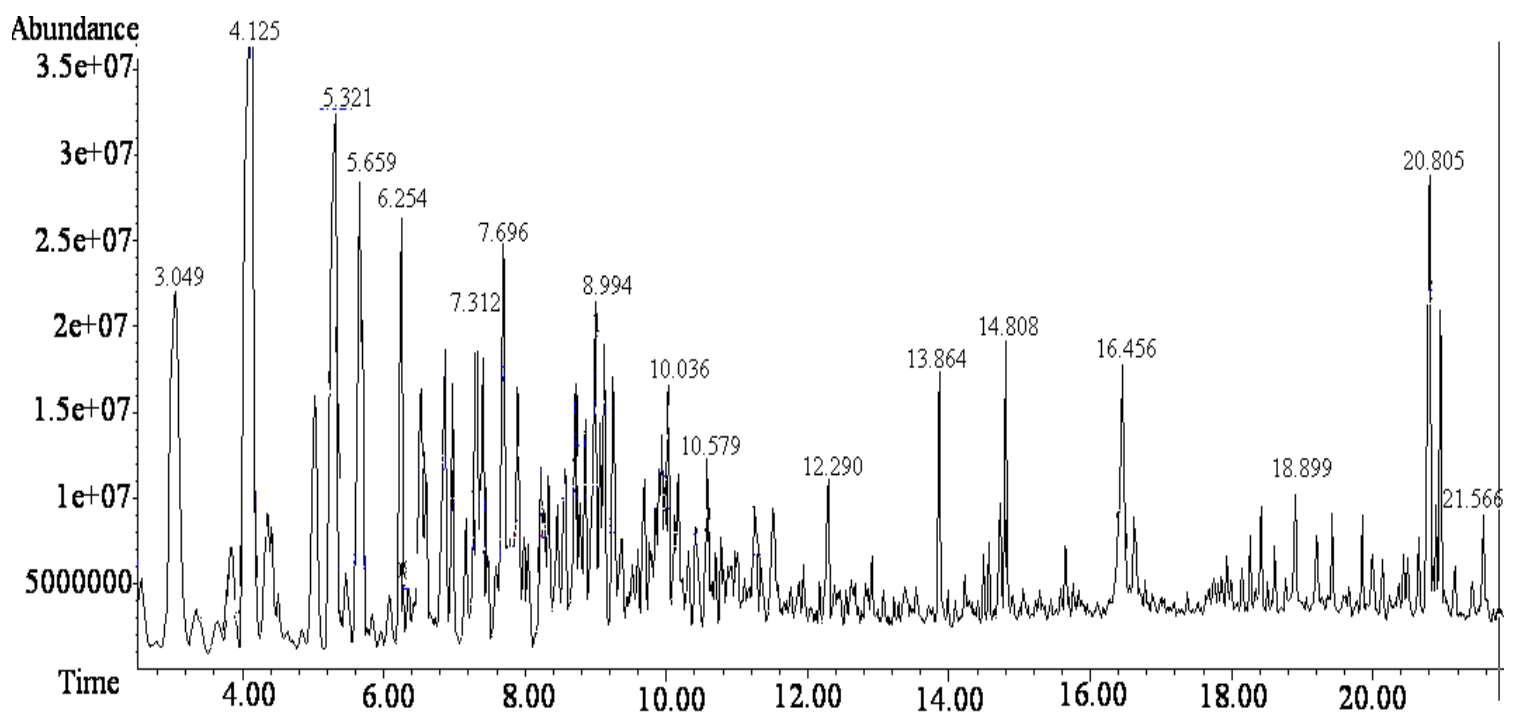

Retention time, min

Figure 10. GC/MS chromatogram of dichlorometane soluble fraction

All registered and identified peaks of GC/MS analysis for pyrolysis tar of shell soluble in hexane, benzene, and dichloromethane fractions are given in Table 7 and the names of all identified peaks are in appendix-1.

Table 7. All registered and identified peaks of GC/MS chromatograms of each fractions

\begin{tabular}{llllllll}
\hline \multirow{2}{*}{$\begin{array}{l}\text { GC/MS } \\
\text { of tar }\end{array}$} & $\begin{array}{l}\text { Hexane } \\
(\mathrm{H}) \%\end{array}$ & soluble fraction & $\begin{array}{l}\text { Benzene } \\
\text { (B) } \%\end{array}$ & soluble fraction & $\begin{array}{l}\text { Dichloromethane } \\
\text { fraction (M) } \%\end{array}$ & soluble \\
\cline { 2 - 7 } & $\begin{array}{l}\text { All } \\
\text { registered } \\
\text { peaks }\end{array}$ & $\begin{array}{l}\text { All } \\
\text { identified } \\
\text { peaks }\end{array}$ & $\begin{array}{l}\text { All } \\
\text { registered } \\
\text { peaks }\end{array}$ & $\begin{array}{l}\text { All } \\
\text { identified } \\
\text { peaks }\end{array}$ & $\begin{array}{l}\text { All registered } \\
\text { peaks }\end{array}$ & $\begin{array}{l}\text { All } \\
\text { peaks }\end{array}$ & identified \\
\hline $\begin{array}{l}\text { GC/MS chromatograms } \\
\text { peak }\end{array}$ & 55 & 48 & 91 & 39 & 65 & 29 \\
\hline
\end{tabular}

As a results of GC/MS analysis for pyrolysis tar of shell soluble in hexane, benzene and dichloromethane fractions 
determined and identified 48 (from all registered 55 hexane soluble compounds), 39 (from all registered 91 benzene soluble compounds) and 29 (from all registered 65 dichloromethane soluble compounds) organic compounds (appendix-1). In general, pyrolysis tars organic raw materials to be extremely complex mixtures. Pioneering GCMS analyses have shown that biomass pyrolysis tars contain very large numbers of chemical components, significant proportions of which are oxygenated compounds (Morgan \& Kandiyoti, 2014).

\section{Conclusions}

1. On the basis of proximate, ultimate, and FTIR analysis, it can be concluded that the shell is an organic raw material which is suitable for pyrolysis. The shell's ash contains high potassium.

2. The results of the pyrolysis experiment of shell show that $29.98 \%$ of shell organic mass remained as a hard residue after pyrolysis. The yield of liquid and gas products is $70.02 \%$ which shows that there was an intensive thermal decomposition of the shell organic mass with a higher degree of conversion.

3. As a results of GC/MS analysis of tar of shell soluble in hexane, benzene and dichloromethane fractions determined and identified 48 (from all registered 55 hexane soluble compounds), 39 (from all registered 91 benzene soluble compounds) and 29 (from all registered 65 dichloromethane soluble compounds ) organic compounds. These are consist of carbons like aromatic and alkyl-aromatic, long-chain aliphatic.

4. Therefore, the FTIR spectra and GC/MS analysis of pyrolysis tar of shell show that the tar is multifunctional complex organic material with bad smelts and black-brown color.

5. The prepared activated carbon of pyrolysis hard residue of shell and the pyrolysis hard residue of shell were tested for methylene blue and iodine adsorption and the results show that the methylene blue adsorption strongly increased 25 times and iodine adsorption 45 times increased than that of pyrolysis hard residue, which are an indication for a good activated carbon.

6. On the basis of thermogravimetric analysis of shell have been determined following thermal stability indices such as $\mathrm{T}_{5 \%}=72.49{ }^{\circ} \mathrm{C} ; \mathrm{T}_{15 \%}=266.27{ }^{\circ} \mathrm{C} ; \mathrm{T}_{25 \%}=295.39^{\circ} \mathrm{C}$. These thermal stability indices show that shell has lower thermal stability and a bid exothermic reaction peak at $300{ }^{\circ} \mathrm{C}$ related to intensive thermal destruction of the coal organic mass of the sample.

7. The proximate analysis results of hard residue after pyrolysis of shell show that the volatile matter content decreased 10 times and much more increased caloric value in comparison with the initial shell characteristics, which are an indication for intensive thermal decomposition of the organic mass of the shell. Due to the carbonization process of its organic mass, there is slightly increasing the ash content.

\section{References}

Ariunaa, A., Bao-Qing, L., Wen, L., Purevsuren, B., Munkhjargal, S., Fen-rong, L., \& Gang, W. (2007). Coal pyrolysis under synthesis gas, hydrogen and nitrogen. Journal of Fuel Chemistry and Technology, 35(1-4). https://doi.org/10.1016/S1872-5813(07)60007-3

Avid, B., \& Purevsuren, B. (2002). Pyrolysis and TG analysis of the Shivee Ovoo coal Mongolia. Journal of Thermal Analysis and Calorimetry, 68(3), 877-885. https://doi.org/10.1023/A:1016130203799

Avid, B., Purevsuren, B., \& Dugarjav, J. (2000). Pyrolysis and thermogravimetrical investigation of the Mongolian Khoot oil shale. Oil Shale, 17(3), 241-251.

Batbileg, S., Purevsuren, B., Davaajav, Y., Namkhainorov, J., Chin-Jung, lin, Krooss, B. M., \& Philipp, W. (2015). Characterization of solid and liquid products obtained from thermal processing of Khoot coal and evaluation of char-made activated carbon adsorption, 159-165.

Davaajav, Y., \& Purevsuren, B. (2006). Investigation on pyrolysis of some organic raw materials. Ulaanbaatar: Toonotprint.

Monkhoobor, D., \& Batchimeg, G. (2009). molecule structure and spectroscopy.

Morgan, T. J., \& Kandiyoti, R. (2014). Pyrolysis of Coals and Biomass: Analysis of Thermal Breakdown and Its Products. Chemical Reviews, 114(3), 1547-1607. https://doi.org/10.1021/cr400194p

Munkhjargal, S., \& Purevsuren, B. (1998). Products of pyrolysis of wood wastes. Reports of the Institute of Chemistry and Chemical Technology, Mongolian Academy of Sciences, 25-28.

Otgonchuluun, D., Ariunaa, A., \& Purevsuren, B. (2015). Pyrolysis wood waste and characterization of obtained products, Reports of the Mongolian University of Science and Technology, 12(176), 68-71.

Purevsuren, B. (1987). Synthesis of some new epoxide resins with higher thermal stability. Institute of Chemical 
technology,Sofia,Bulgaria.

Purevsuren, B. (2012). Investigation on pyrolysis of shell. Proceedings of the Mongolian Academy of Sciences, 52(2), 45-52. https://doi.org/10.5564/pmas.v52i2.359

Purevsuren, B., \& Davaajav, Y. (2001a). Investigation on pyrolysis of casein. Journal of Thermal Analysis and Calorimetry, 66, 743-748. https://doi.org/10.1023/A:1013135920477

Purevsuren, B., \& Davaajav, Y. (2001b). Thermal analysis of casein. Journal of Thermal Analysis and Calorimetry, 65, 147-152. https://doi.org/10.1023/A:1011532819792

Purevsuren, B., \& Ochirbat, P. (2016). Comparative study of pyrolysis and thermal dissolution of Estonian and Mongolian Khoot oil shales. Oil Shale, 33(4), 329-339. https://doi.org/10.3176/oil.2016.4.02

Purevsuren, B., Avid, B., Narangerel, J., Gerelmaa, T., \& Davaajav, Y. (2004). Investigation on the pyrolysis products from animal bone, Journal of materials science. Journal of Materials Science, 39, 737-340. https://doi.org/10.1023/B:JMSC.0000011545.51724.ad

Purevsuren, B., Davaajav, Y., Batbileg, S., Ariunaa, A., Namkhainorov, J., Jargalmaa, S., ... Dugarjav, J. (2017). Investigation on pyrolysis of some organic raw materials. Mongolian Journal of Chemistry, 17(43), 5-13. https://doi.org/10.5564/mjc.v17i43.739

Purevsuren, B., Davaajav, Y., F, K., Morgan, T., George, A., Herod, A., \& Kandiyoti, R. (2009). Pyrolysis of waste polypropylene and characterization of the tar. European Journal of Mass Spectrometry, 15(1), 23-33. https://doi.org/10.1255/ejms.975

Purevsuren, B., Davaajav, Y., Karaca, F., Morgan, T. J., George, A., Herod, A. A., \& Kandiyoti, R. (2009). Pyrolysis of Waste Polypropylene and Characterisation of Tar. European Journal of Mass Spectrometry, 15(1), 23-33. https://doi.org/10.1255/ejms.975 
Appendix-1.The name of determined organic substances by GC/MS chromatography

\begin{tabular}{|c|c|c|c|c|c|c|c|c|}
\hline \multicolumn{3}{|r|}{ Soluble in Hexane fraction } & \multicolumn{3}{|c|}{ Soluble in Benzene fraction } & \multicolumn{3}{|c|}{ Soluble in Dichloromethane fraction } \\
\hline$R . T$ & $\%$ of & The name of determined organic & $R . T$ & $\%$ of & The name of determined organic & $R . T$ & $\%$ of & The name of determined \\
\hline 1.527 & 23.240 & Hexan & 1.585 & 3.182 & Benzene & 1.642 & 7.309 & Benzene \\
\hline 2.254 & 0.796 & Dimethyl benzene & 3.833 & 3.754 & 2-methyl, phenol & 2.569 & 1.202 & 1-(2-furanyl) ethanone, \\
\hline 2.935 & 0.744 & Methyl ethyl benzene & 4.074 & 1.212 & 4-methyl, phenol & 3.049 & 7.122 & Phenol \\
\hline 3.244 & 1.195 & Benzene cyclopropyl & 4.383 & 6.494 & 4-methoxy, phenol & 3.833 & 1.508 & 2-methyl phenol \\
\hline 3.559 & 0.724 & Diethyl benzene & 4.566 & 2.302 & 2, 4-dimethyl, phenol & 4.125 & 12.318 & 3-methyl phenol \\
\hline 5.167 & 2.864 & Benzene (cyclopopenyl 1-methyl) & 4.875 & 0.771 & 2-ethyl, phenol & 4.354 & 1.318 & 2-methoxy phenol \\
\hline 5.641 & 4.448 & Naphthalene & 5.275 & 2.066 & 2,3-dimethyl, phenol & 5.023 & 3.072 & dimethyl phenol \\
\hline 6.557 & 1.102 & 1,3-dimethyl, $1 \mathrm{H}$-indene & 5.756 & 6.899 & 2-methoxy 4-methyl, phenol & 5.321 & 7.374 & dimethyl phenol \\
\hline 6.912 & 0.845 & 1-Tridecene & 6.059 & 2.218 & 4,7- dimethyl Benzofuran & 5.470 & 0.700 & dimethyl phenol \\
\hline 7.135 & 4.136 & 1-methyl naphthalene & 6.260 & 2.991 & 2-ethyl 6-methyl, phenol & 5.659 & 3.832 & dimethyl phenol \\
\hline 7.375 & 2.720 & 2-methyl naphthalene & 6.540 & 1.610 & 2- $(2$ methylpropyl $)$ phenol & 6.254 & 2.890 & 2,3-dimethyl toluene \\
\hline 8.258 & 1.033 & 2-Tetradecene & 6.952 & 5.985 & Methoxy ethylphenol & 6.528 & 2.072 & 3-ethyl 5-methyl phenol \\
\hline 8.594 & 0.726 & 2,7- dimethyl, naphthalene & 7.209 & 2.614 & 1-methyl Naphthalene, & 6.866 & 2.359 & 4-ethyl 2-methoxy phenol \\
\hline 8.794 & 0.833 & 2,3-dimethyl, naphthalene & 7.352 & 1.344 & 2-methoxy 4-vinylphenol & 6.975 & 1.443 & 2,3-dihydro $1 \mathrm{H}$ inden \\
\hline 8.840 & 0.973 & 1,7-dimethyl, naphthalene & 7.947 & 3.276 & 2-methoxy 3-(2-propenyl) phenol & 7.163 & 0.708 & 2-methyl naphthalene \\
\hline 9.286 & 0.837 & Benzene, octyl & 8.096 & 3.177 & 3-ethoxy 4-gidroxy Benzaldehyde & 7.312 & 2.173 & 2-ethyl 3-methoxy pyrazine \\
\hline 9.532 & 0.914 & 1-Pentadecene & 8.291 & 0.659 & Biphenyl & 7.404 & 1.059 & 4-ethyl 1,2-dimethoxy \\
\hline 9.624 & 1.560 & Pentadecene & 8.611 & 1.657 & 2-methoxy-4-(1-propenyl) phenol & 7.696 & 2.212 & 6-methoxy o-cresol \\
\hline 10.562 & 0.698 & Benzene, nonyl & 8.834 & 1.205 & 1,7-dimeyhyl naphthalene & 7.896 & 1.267 & 1H-indenol \\
\hline 10.745 & 1.047 & 1-Hexadecene & 8.886 & 0.830 & 2,6-dimeyhyl naphthalene & 8.714 & 1.336 & 2-methyl 5 \\
\hline 10.831 & 0.961 & Hexadecene & 9.195 & 6.230 & 2-methoxy-4-(1-propenyl) phenol & 8.994 & 2.131 & 3,4-methylenedioxyamisole \\
\hline 11.747 & 0.908 & Benzene, decyl & 10.213 & 0.791 & 1,6,7-trimeyhyl naphthalene & 9.126 & 1.578 & 2-methoxy-4-(1-propenyl) \\
\hline 11.804 & 0.858 & 8-Heptadecene & 10.425 & 0.862 & 1,4,6-trimeyhyl naphthalene & 9.246 & 1.644 & 5,7-dimethyl 1H-indazole \\
\hline 11.896 & 0.983 & 1-Heptadecene & 10.213 & 0.791 & Naphthalene, 1,6,7-trimeyhyl & 10.036 & 0.865 & 2- naphthalenol \\
\hline 11.976 & 1.325 & Heptadecene & 10.425 & 0.862 & Naphthalene, 1,4,6-trimeyhyl & 13.864 & 1.160 & 1,2-benzenedicarboxylic \\
\hline 12.325 & 1.189 & 1,2-isohexyl 6-methyl, 1-heptene & 10.889 & 0.556 & 9 H fluorene & 14.808 & 1.182 & dibutyl phathalate \\
\hline 12.445 & 0.733 & 1,2,3-trimethyl, cyclohexane & 10.940 & 0.787 & 1,4,5-trimeyhyl naphthalene & 16.456 & 1.938 & 9-Octadecenoic acid \\
\hline 12.988 & 1.343 & 1-Octadecene & 11.169 & 0.905 & 2-methyl 1-naphthalenol & 20.805 & 2.813 & Tribenzo $(a, c, e)$ cycloocten \\
\hline 13.063 & 1.069 & Octadecene & 12.657 & 0.483 & 1,2-dimethyl naphtho (2,1-6) & 20.959 & 1.199 & 2-(3,4-dimethoxy phenyl) \\
\hline 14.030 & 1.378 & 1-Nonadecene & 13.154 & 1.326 & Phenanthrene & & & \\
\hline 14.063 & 1.467 & Nonadecane & 14.379 & 1.731 & Hexadecanoic acid, methyl ester & & & \\
\hline 15.020 & 1.429 & 1-Octadecene & 15.838 & 0.433 & di-p-Tolylacetylene & & & \\
\hline 15.077 & 1.525 & Eicosane & 16.015 & 0.547 & 9,12-octadecadienoic acid, & & & \\
\hline 15.140 & 0.839 & Dimethyl, phenanthrene & 16.078 & $1.448 \%$ & 9- octadecanoic acid, methyl & & & \\
\hline 15.512 & 1.317 & Dimethyl isopropyl & 16.124 & $0.890 \%$ & 9- octadecanoic acid, methyl & & & \\
\hline 15.958 & 1.078 & 10-Heneicosene & 16.284 & $0.672 \%$ & 9- octadecanoic acid, methyl & & & \\
\hline 16.015 & 1.586 & Heneicosene & 16.822 & $0.552 \%$ & 2,3,5-trimethyl phenanthrene & & & \\
\hline 16.862 & 1.116 & 1-Docosene & 17.383 & $1.037 \%$ & 1-methyl-7-(1-methylethyl) & & & \\
\hline 16.914 & 1.400 & Docosane & 18.379 & $0.402 \%$ & 1-Phenanthrenecarboxyhi acid, & & & \\
\hline 17.732 & 1.087 & 9-Tricosene & 21.142 & $0.284 \%$ & Tetracosanoic acid, methyl ester & & & \\
\hline 17.772 & 2.209 & Tricosane & & & & & & \\
\hline 18.562 & 2.373 & Cyclotetracosane & & & & & & \\
\hline 18.602 & 1.108 & Tetracosane & & & & & & \\
\hline 19.397 & 1.556 & Pentacosane & & & & & & \\
\hline 20.130 & 1.109 & 1-Hexacosene & & & & & & \\
\hline 20.902 & 0.968 & Heptacosane & & & & & & \\
\hline 23.786 & 0.984 & 2-Anthracenecarboxylic acid, & & & & & & \\
\hline 24.375 & 5.907 & 3,5-diene Stigmastan & & & & & & \\
\hline
\end{tabular}

\section{Copyrights}

Copyright for this article is retained by the author(s), with first publication rights granted to the journal.

This is an open-access article distributed under the terms and conditions of the Creative Commons Attribution license (http://creativecommons.org/licenses/by/4.0/). 